BMJ Open Diabetes Research \& Care

To cite: Weinrauch LA, D'Elia JA. Renal transplant outcomes and diabetes. BMJ Open Diab Res Care 2021;9:e002294. doi:10.1136/ bmjdrc-2021-002294

Received 7 April 2021 Accepted 11 April 2021

\section{Linked}

- http://dx.doi.org/10.1136/ bmjdrc-2020-001962

Check for updates

(C) Author(s) (or their employer(s)) 2021. Re-use permitted under CC BY-NC. No commercial re-use. See rights and permissions. Published by BMJ.

${ }^{1}$ Kidney and Hypertension Section, Joslin Diabetes Center, Boston, Massachusetts, USA ${ }^{2}$ Harvard Medical School, Boston, Massachusetts, USA

Correspondence to Dr Larry A Weinrauch; larry_weinrauch@hms.harvard. edu

\title{
Renal transplant outcomes and diabetes
}

\author{
Larry A Weinrauch 주 , ${ }^{1,2}$ John A D'Elia $^{1}$
}

Designing and performing new trials requires extraordinary expenditures of effort, time and money. Less costly and often surprisingly helpful are efforts to revisit existing databases with current advanced epidemiologic analyses. The subject of kidney transplantation is particularly relevant due to the high cost of chronic dialysis with its accompanying lifestyle impediments indicating the need to identify reasons for slow progress in treating end-stage renal disease (ESRD).

Harding et al in this issue of the journal sift through a massive amount of data collected in the United States Renal Data System (USRDS), using statistical equations to analyze relationships between diabetes and both patient and graft survival outcomes after an initial kidney transplant. More than 250000 new kidney transplant recipients were identified with more than 72000 subsequent deaths. Outcome data were evaluated for diabetes mellitus as physician-assigned primary cause of ESRD for adults listed in the USRDS between 2000 and 2018, elucidating a contemporary database fraught with limitations, biases and confounders. Admirably, they stay on target, demonstrating that adjusting for the available variables, the presence of diabetes increases the likelihood of adverse outcome. Regardless of the origin of the donor organ, adjusted mortality rates are $75 \%$ higher with rates of adjusted graft losses $25 \%$ higher in cohorts identified by diagnosis of diabetes in the allograft recipient. For those familiar with kidney transplantation, these findings are not surprising.

How then does this manuscript derive importance enough to merit publication? We would submit that it is the journey through these data that will lead to important observations. Analysis of these data by Harding et al elucidates a need to expand data accumulation in persons with diabetes to improve outcome following kidney transplantation. Among these we must note that:

1. There are flaws in the database that require correction in order to explain why the diabetic cohort still does not attain some of the benefits achieved in the non-diabetic cohort.

a. Does either duration or severity of glucose intolerance play a role?

b. How long were the cohorts exposed to prior forms of renal replacement?

c. What is the impact of invasive cardiovascular therapies?

d. How much misclassification is prevalent in the USRDS database?

2. The USRDS is a powerful resource that should be mined for additional information that may focus our attention on where we can improve care.

a. We note an imbalance of care that has led to greater than $60 \%$ of initial kidney recipients being male with less than $40 \%$ female.

b. Mortality being significantly higher in the non-Hispanic white cohort and graft failure being higher within the nonHispanic black cohort.

c. A decrease in age standardized mortality is noted during the last decade. It is unclear whether this is associated with increases body mass index and rising rates of obesity or represents increased susceptibility to infections from current immunomodulation protocols.

d. Data are generally unavailable regarding diabetes diagnosed after the transplantation procedure. ${ }^{1}$

3. Information regarding underlying disease leading to kidney transplantation is not sufficiently granular. Non-diabetic cohorts are populated by glomerular lesions associated with hypertension with or without unique genetic or immunologic processes. Cohorts with diabetes exhibit higher cardiovascular and immune-deficiency risk than non-diabetic transplant recipient cohorts. Statistical methods that assess associated relationships do not substitute for documentation of pathology indicating cause. Type 1 diabetes is insulinopenic because the immune system destroys beta cells. Is there another process immunologically involved that raises the risk to a 
donated kidney? Type 2 diabetes is associated with insulin resistance followed by insulinopenia. Finding a root cause that can be treated in allograft recipients could increase survival. Future analyses should focus on SGLT-2 inhibition for non-glycemia-related effects on preservation of renal function in the type 2 diabetes population. ${ }^{2}$ Should we be focusing on SGLT2 inhibition or GLP-1 receptor antagonism for their non- glycemia related and non-diuretic effects in the type 2 diabetic population? ${ }^{3-7}$

We hope that the data presented by Harding et al will stimulate efforts to improve outcome for persons with ESRD and diabetes mellitus who become candidates for transplantation.

Contributors Both authors contributed equally to this editorial.

Funding The authors have not declared a specific grant for this research from any funding agency in the public, commercial or not-for-profit sectors.

Competing interests None declared.

Patient consent for publication Not required.

Provenance and peer review Commissioned; internally peer reviewed.

Open access This is an open access article distributed in accordance with the Creative Commons Attribution Non Commercial (CC BY-NC 4.0) license, which permits others to distribute, remix, adapt, build upon this work non-commercially, and license their derivative works on different terms, provided the original work is properly cited, appropriate credit is given, any changes made indicated, and the use is non-commercial. See: http://creativecommons.org/licenses/by-nc/4.0/.

ORCID ID

Larry A Weinrauch http://orcid.org/0000-0003-1357-9528

\section{REFERENCES}

1 et alDavidson J, Wilkinson A, Dantal J. International expert panel. new-onset diabetes after transplantation: 2003 international consensus guidelines. Proceedings of an international expert panel meeting, 2003:SS3-24.

2 Wanner C, Heerspink HJL, Zinman B, et al. Empagliflozin and kidney function decline in patients with type 2 diabetes: a slope analysis from the EMPA-REG outcome trial. J Am Soc Nephrol 2018;29:2755-69.

3 Bonora BM, Avogaro A, Fadini GP. Extraglycemic effects of SGLT2 inhibitors: a review of the evidence. Diabetes Metab Syndr Obes 2020;13:161-74.

4 Packer M, Anker SD, Butler J, et al. Cardiovascular and renal outcomes with Empagliflozin in heart failure. N Engl J Med 2020;383:1413-24.

5 Herzlinger S, Horton ES. Extraglycemic effects of glp-1-based therapeutics: addressing metabolic and cardiovascular risks associated with type 2 diabetes. Diabetes Res Clin Pract 2013;100:1-10.

6 Packer M, Anker SD, Butler J, et al. Empagliflozin in Patients With Heart Failure, Reduced Ejection Fraction, and Volume Overload: EMPEROR-Reduced Trial. J Am Coll Cardiol 2021;77:1381-92.

7 Kalyani RR. Glucose-Lowering drugs to reduce cardiovascular risk in type 2 diabetes. N Engl J Med 2021;384:1248-60. 